\title{
The composition of kukersite shale oil
}

\author{
Zachariah Steven Baird, Vahur Oja, Oliver Järvik*
}

Department of Energy Technology, Tallinn University of Technology, Ehitajate tee 5, 15006 Tallinn, Estonia

Received 16 September 2022, accepted 20 January 2023, available online 10 February 2023

\begin{abstract}
Pyrolysis oils are usually considered as substitutes for crude oil; however, they can also be sources of valuable compounds. One such pyrolysis oil is shale oil obtained by pyrolysis of kukersite oil shale. Kukersite shale oil consists mainly of aromatic rings with straight alkyl side chains. For samples with comparable boiling point distributions, kukersite shale oil has a higher proportion of aromatic rings than petroleum and many other shale oils. Sulfur, nitrogen, and oxygen are often incorporated into the ring structures, with much of the oxygen also present as phenolic hydroxyl groups.

To evaluate the potential for producing some specific compounds from kukersite shale oil foundational data on the composition is needed. In this article, new experimental data on the elemental composition and infrared spectrum of kukersite shale oil is analyzed to investigate its composition. To get detailed information on how the composition of the oil changes depending on the average molecular weight of the oil fraction, the shale oil was separated into narrow boiling fractions using distillation. This gives more detailed data on different portions of the oil than earlier datasets. Additionally, this data is for oil produced from newer solid heat carrier retorts. The results show that the nitrogen content in kukersite shale oil increases with the boiling temperature, with the heaviest fractions containing about $0.3 \mathrm{wt} \%$. Sulfur content reaches a maximum of almost $2 \mathrm{wt} \%$ for fractions boiling between 150 and $190{ }^{\circ} \mathrm{C}$, and heavier fractions contain about $0.7 \mathrm{wt} \%$. Similarly, the proportion of hydroxyl groups in kukersite shale oil peaks in the fraction boiling at about $320^{\circ} \mathrm{C}$, with heavier fractions containing more aromatic and alkyl functional groups. The elemental composition of kukersite shale oil is also compared to that of other shale oils.
\end{abstract}

Keywords: kukersite, shale oil, sulfur, nitrogen, FTIR spectroscopy, functional groups.

\footnotetext{
* Corresponding author: e-mail oliver.jarvik@taltech.ee

(C) 2023 Authors. This is an Open Access article distributed under the terms and conditions of the Creative Commons Attribution-NonCommercial 4.0 International License (http://creativecommons.org/licenses/by-nc/4.0/).
} 


\section{Introduction}

Oil shale is a solid fossil fuel that has at times been seen as a promising energy source due to the large reserves available. Oil shale can be burned directly, like coal, or converted into a liquid fuel called shale oil. Like petroleum, shale oil can also be used for chemical production. It has been estimated that 4.7 trillion barrels of oil could be produced from the known oil shale reserves [1], which is significantly larger than current petroleum reserves. However, its use has generally been hampered by economic and environmental challenges [2], and these environmental issues are especially relevant given the EU climate policy. And importantly, the link between fossil fuel usage and climate change means that using oil shale as a fuel is most likely environmentally unsustainable [3]. In spite of its environmental challenges though, shale oil is still produced in several countries, including China, Estonia, and Brazil [1, 4]. In Estonia, several new oil plants have been built in just the last decade, and one more is currently under construction [5].

Instead of simply burning shale oil as fuel, it could instead be used as a potential source of more valuable chemical products. This might help reduce the emissions from shale oil usage and provide shale oil companies with additional revenue streams. Data on the composition of shale oils could enable such chemical products to be developed that add value and help transition to the more sustainable utilization of oil shale.

Oil shales are sedimentary rocks that contain significant amounts of solid organic matter. The organic matter can make up anywhere from 5 to $70 \%$ of the rock [6], which means that oil shales contain significant amounts of inorganic matter. Oil shale can be burned directly, or it can be processed to create a synthetic liquid fuel known as shale oil (not to be confused with tight oil, which is also called shale oil, but is a conventional petroleum liquid that is simply trapped in a shale formation). To produce oil an oil shale is heated and the organic matter fragments into smaller molecules in a process called pyrolysis $[6,7]$.

Like most unconventional oils, shale oils often have a composition that is quite different from that of conventional petroleum liquids. Many shale oils contain large quantities of olefinic and aromatic compounds. Most shale oils also contain significant quantities of heteroatomic compounds. Because the composition also affects the properties of the oil, it is important to understand and account for the compositional differences of unconventional oils. Knowledge of the molecular structures in the oil is also needed to be able to identify potential chemicals that could be produced from the oil.

The composition of shale oils varies widely and is dependent on the composition of the parent oil shale and on the retorting method used (a plant that produces shale oil is called a retort). This study in particular investigated shale oil produced from kukersite oil shale, which is found in Estonia. Kukersite shale oil is interesting because it contains roughly $30 \%$ phenolic compounds 
$[8,9]$. These polar oxygen compounds give kukersite oil a composition that is somewhere between conventional petroleum and a biomass oil. Using elemental composition data and infrared spectra for more than 300 narrow fractions, we analyzed how heteroatoms are distributed in kukersite shale oil and estimated the average amount of different functional groups.

\section{Experimental}

\subsection{Sample preparation}

Shale oil samples were obtained from the Enefit Shale Oil Plant in Narva, Estonia, which uses the solid heat carrier (Galoter) process [10, 11]. The crude oil is separated at the plant into three fractions: gasoline, fuel oil (also referred to as the "middle oil fraction" in some older Galoter process based publications) and heavy oil. The process was described in detail in an earlier article by Järvik et al. [12]. One fuel oil sample was from the newer Enefit 280 technology and the other samples were from the Enefit 140 technology (also called the UTT 3000 technology in older publications). These samples were separated into narrow boiling range fractions using distillation. Most of the fractions spanned distillation temperature intervals of about 5 to $10{ }^{\circ} \mathrm{C}$. Some extractions were also performed to separate the phenolic compounds from the fuel oil, and this created dephenolated and phenol-rich oil samples that were also studied.

\subsection{Elemental analysis}

A CE-440 Exeter elemental analyzer (Exeter Analytical Inc.) was used to determine the carbon and hydrogen contents of the samples. The estimated standard uncertainties of the carbon and hydrogen contents were, respectively, $0.36 \mathrm{wt} \%$ and $0.084 \mathrm{wt} \%$ (estimated expanded uncertainties of $0.72 \mathrm{wt} \%$ and $0.17 \mathrm{wt} \%$ at the $95 \%$ level). Sulfur content was measured using a Lab-X 3500 Benchtop XRF Analyser (Oxford Instruments), which uses the ASTM D 4294 method. The estimated standard uncertainty of the sulfur measurements was $0.0024 \mathrm{wt} \%$ (expanded uncertainty of $0.0043 \mathrm{wt} \%$ at the $95 \%$ level). Nitrogen content was measured with a Nitrogen Detector Model ND-100 (Mitsubishi Chemical Analytech), following the ASTM D 5762-09 standard. The estimated standard uncertainty for these nitrogen measurements was $0.0014 \mathrm{wt} \%$ (expanded uncertainty of $0.0024 \mathrm{wt} \%$ at the $95 \%$ level). The standard uncertainties for these parameters were determined as the average of the standard deviations for different samples.

The data used for the analysis in this article was part of a larger study to investigate the properties of kukersite shale oil. The elemental composition data and additional properties of the samples studied here were given in the earlier articles by Järvik et al. [12], Mozzafari et al. [13], and Järvik and Oja 
[14], the data can also be found from the Open Science Framework repository (https://osf.io/3q5ur).

\subsection{Infrared measurements}

Infrared (IR) spectra were obtained using an Interspec 301-X spectrometer (Interspectrum OÜ) that was fitted with an attenuated total reflection (ATR) accessory having a ZnSe crystal. The ATR accessory had a single reflection internal reflection element. Interspec for Windows software (version 3.40 Pro, Interspectrum OÜ) was used to collect the spectra. Spectra were obtained between 700 and $4000 \mathrm{~cm}^{-1}$ at a resolution of $1 \mathrm{~cm}^{-1} .10$ scans were averaged together to obtain each spectrum. The baseline of each spectrum was then corrected using a third-order polynomial fit to regions where the shale oil did not absorb (2000-2200 and 3700-4000 $\mathrm{cm}^{-1}$ ).

The infrared spectra can be obtained from the OSF repository for this project (https://osf.io/5379p/).

\subsection{Functional group analysis}

Because shale oils are complex mixtures of many different molecules, it is currently not feasible to determine the exact composition of the mixture. We were, however, able to estimate the amounts of various functional groups in the shale oil fractions. We did this based on the elemental composition, molar mass, and infrared spectra of the samples. The main functional groups in kukersite shale oil are listed in the Table. The topological polar surface areas were calculated employing the RDKit package [15], which uses the method by Ertl et al. [16]. The topological polar surface area, hydrogen bond donor, and hydrogen bond acceptor columns are added to give some additional information about the polarity of each functional group and its propensity to form hydrogen bonds.

Table. Major functional groups in kukersite shale oil

\begin{tabular}{|c|c|c|c|c|}
\hline Group & Structure & $\begin{array}{c}\text { Topological polar } \\
\text { surface area }\end{array}$ & $\begin{array}{c}\text { Hydrogen } \\
\text { bond donor }\end{array}$ & $\begin{array}{c}\text { Hydrogen bond } \\
\text { acceptor }\end{array}$ \\
\hline Methyl C & $-\mathrm{CH}_{3}$ & 0 & 0 & 0 \\
Methylene C & $-\mathrm{CH}_{2}-$ & 0 & 0 & 0 \\
$\begin{array}{c}\text { Aromatic and } \\
\text { double bonded C } \\
\mathrm{C}=\mathrm{C} \text { or } \\
\text { Carbonyl }\end{array}$ & $\begin{array}{c}-\mathrm{C}=\mathrm{O} \\
\text { Hydic ring }\end{array}$ & 17.07 & 0 & 0 \\
\hline $\mathrm{OH}$ & 20.23 & 1 & 1 \\
\hline
\end{tabular}


Table (continued)

\begin{tabular}{|c|c|c|c|c|}
\hline Group & Structure & $\begin{array}{l}\text { Topological polar } \\
\text { surface area }\end{array}$ & $\begin{array}{l}\text { Hydrogen } \\
\text { bond donor }\end{array}$ & $\begin{array}{c}\text { Hydrogen bond } \\
\text { acceptor }\end{array}$ \\
\hline Furan & $-\mathrm{O}-$ in a ring & 13.14 & 0 & 1 \\
\hline Thiophene & $\begin{array}{c}\mathrm{S} \text { in a } \\
\text { five-membered } \\
\text { ring }\end{array}$ & 28.24 & 0 & 1 \\
\hline $\begin{array}{l}\text { Pyridine (also quino- } \\
\text { lines and acridines) }\end{array}$ & $\begin{array}{c}\mathrm{N} \text { in a } \\
\text { six-membered } \\
\text { aromatic ring }\end{array}$ & 12.89 & 0 & 1 \\
\hline $\begin{array}{c}\text { Pyrrole } \\
\text { (also indoles) }\end{array}$ & $\begin{array}{c}\mathrm{N}-\mathrm{H} \text { in a } \\
\text { five-membered } \\
\text { ring }\end{array}$ & 15.79 & 1 & 0 \\
\hline
\end{tabular}

The number of hydroxyl groups could be calculated directly from data on the mass fraction of hydroxyl groups and the molar mass for each sample. The mass fraction of hydroxyl groups was calculated based on the infrared spectra using a machine learning model developed earlier by Baird et al. [9] and by Baird [17]. Most of the oxygen in kukersite shale oil is present as phenolic groups, but it is worth noting that our method for calculating hydroxyl groups also counts any organic acids present in the oil $[9,18]$.

For samples for which full elemental composition data $(\mathrm{C}, \mathrm{H}, \mathrm{N}, \mathrm{S}, \mathrm{O})$ was available, it was possible to calculate the number of sulfur and nitrogen groups per molecule directly. For other samples with no experimental data available, the amount of sulfur and nitrogen was estimated from correlations fit to the fractions for which data was available. This estimation was done simply to make the calculation of oxygen content more accurate. In the fractions boiling below $200{ }^{\circ} \mathrm{C}$ this is more important because both sulfur and oxygen contents are in the range of about 0.5 to $2 \mathrm{wt} \%$. For heavier fractions, though, the content of sulfur and nitrogen is less than $1 \mathrm{wt} \%$, which is small compared to the oxygen content of 3 to $9 \mathrm{wt} \%$.

The number of neutral oxygen groups was calculated by taking the oxygen content of each sample and subtracting the oxygen that was part of hydroxyl groups. For samples for which experimental sulfur and nitrogen data was not available, the uncertainty of this calculation is higher because the oxygen content was calculated based only on estimates of the sulfur and nitrogen content. We expect that the expanded uncertainty of the number of neutral oxygen groups is about $+/-0.1$ group for those samples whose experimental data on the sulfur and nitrogen content was not available.

The proportion of saturated carbons that were methylene groups was estimated from each sample's infrared spectrum. This was done based on the 
height of the peaks at approximately 2920 and $2960 \mathrm{~cm}^{-1}$, which correspond, respectively, to peaks caused by methylene and methyl C-H stretching [19]. Because these peaks overlap, a Cauchy distribution was assumed for both peaks and the equation for this distribution was used to adjust the raw heights to take into account the overlap. When converting the peak heights to group numbers, we assumed that the absorption of a methylene group was only $2 / 3$ of the absorption of a methyl group. This is based on the fact that a methyl group has three $\mathrm{C}-\mathrm{H}$ bonds while a methylene group only has two. This is only an approximation because other factors also influence the absorption, but we did check this assumption by looking at spectra for a few pure compounds and the $2 / 3$ ratio was a reasonable approximation for those compounds.

To calculate the number of carbons with aromatic or double bonds, we essentially calculated the double bond equivalent. This calculation begins with an estimate of the expected number of hydrogens, which we calculated as $2 n+2$, where $n$ is the number of carbon atoms. To exclude rings and get a more accurate count of just double and aromatic bonds, we estimated the number of rings for each fraction using a linear relationship based on data obtained by Gubergrits et al. [20] (also available in [12]) and trends seen in infrared spectral data [17]. We also accounted for the effect of carbonyl and pyrrole groups on the expected number of hydrogens. Then, by subtracting the actual number of hydrogens (from the elemental composition) from the expected number, we were able to determine how many carbons had aromatic or double bonds.

It is important to note that we did not have independent data on the exact number of functional groups in each of the samples to be able to get a good estimate of the uncertainty of our calculations. Therefore, the data on the number of functional groups should be considered qualitative.

The code we used to perform this analysis is also available on OSF (https:// osf.io/rdsjc/).

\section{Results and discussion}

\subsection{Infrared spectra}

From the infrared spectra measured in this project, we can view how the types of functional groups in the oil change as fractions with successively higher boiling points are observed (Fig. 1). This figure includes both shale gasoline and fuel oil fractions. To help interpreting the spectra, look at Figure 11 in the Appendix. The peaks associated with phenolic compounds start to appear at about $200{ }^{\circ} \mathrm{C}$, which is where the gasoline fraction ends and the fuel oil fraction begins. These aromatic and hydroxyl group peaks continue to increase in height up to about $320^{\circ} \mathrm{C}$, at which point a shift starts to take place. Peaks related to saturated $\mathrm{C}-\mathrm{H}$ bonds continue to increase, but 


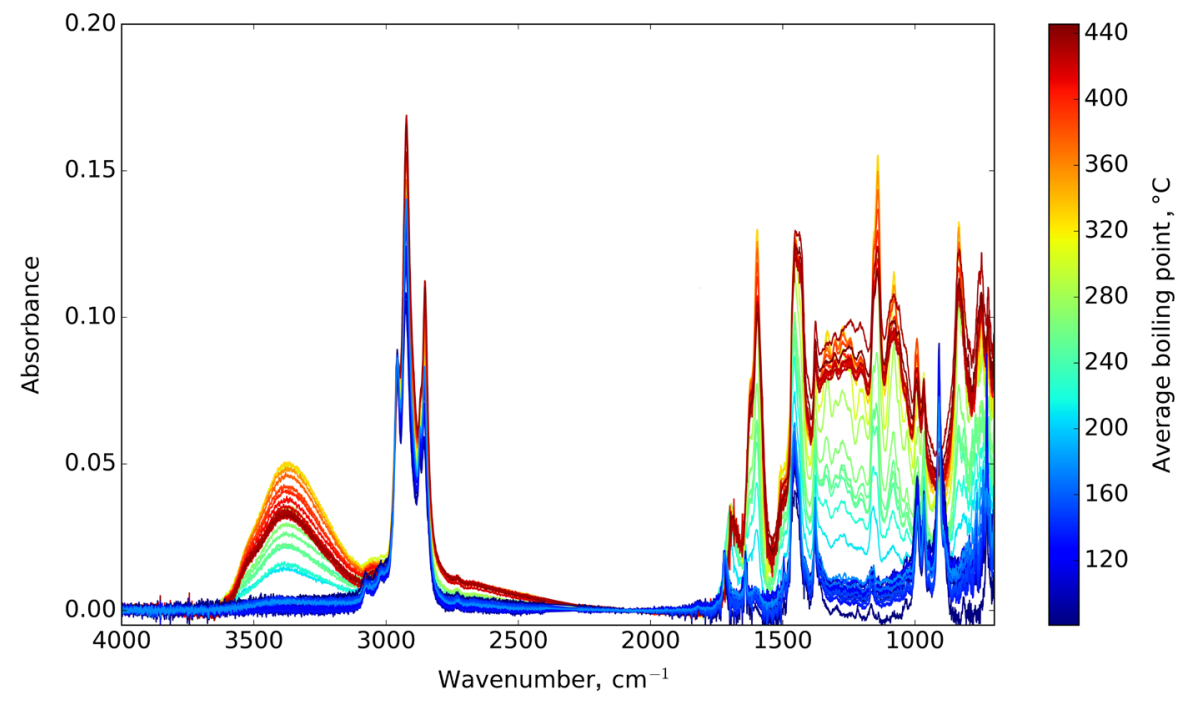

Fig. 1. Changes in the infrared spectra of shale oil fractions with progressively higher boiling points. Figure taken from [17].

the size of the aromatic and hydroxyl peaks decreases somewhat. In the higher boiling fractions the spectrum remains essentially the same, indicating that the relative proportion of the different functional groups continues to be basically the same.

In summary, the fuel oil contains some smaller aromatic compounds, including phenols and resorcinols, that do not have long aliphatic chains. These smaller compounds are distilled first, and the concentration of polar hydroxyl groups is highest in these mid-range fractions. The heavier fractions appear later in the distillation, and these fractions contain the aromatic and phenolic compounds with long straight hydrocarbon chains [9].

By combining these infrared spectra with elemental composition data, we were able to go further and calculate the number and type of various functional groups in an average shale oil molecule with a specific boiling point.

\subsection{Hydrocarbon groups}

As with many other oils, the hydrogen-carbon ratio of kukersite shale oil fractions decreases as the boiling point and density increase. However, the decrease is larger for kukersite oil than for many other oils, and generally, kukersite oil has a lower $\mathrm{H} / \mathrm{C}$ ratio. This is likely due to the different structure of the kerogen in kukersite oil shale. Figure 2 compares the data for kukersite shale oil [12] with data for Green River shale oil (USA) [21-25], Fushun shale oil (China) [26], Sévérac-le-Château shale oil (France) [27], New Albany shale oil (USA) [22], coal liquids [28] and some common petroleum crudes [29]. 


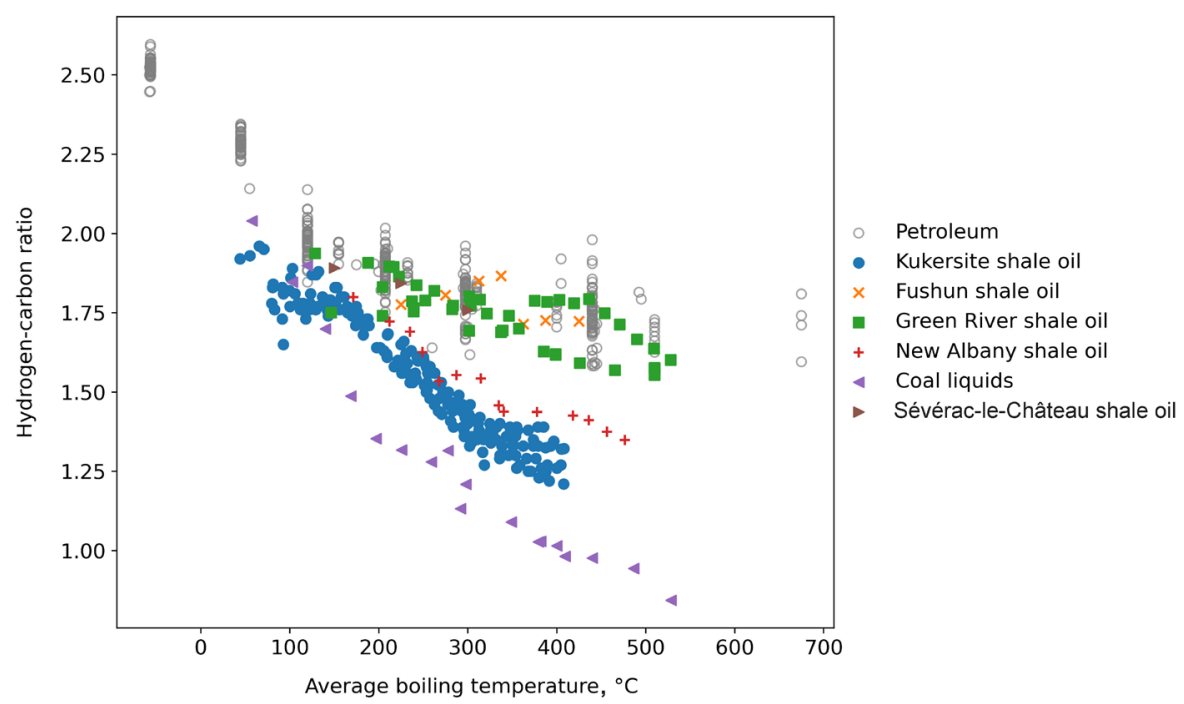

Fig. 2. Hydrogen-carbon ratios for kukersite oil fractions and several other liquid fuels. For all samples besides the kukersite shale oil samples, the average boiling point was taken to be the average of the distillation temperature range of the fraction. Literature data is from [12, 21-29].

The literature data we have compiled is also available on OSF (https://osf.io/ uxk5s/).

Based on the elemental composition data and infrared spectra, it was possible to calculate approximately the relative proportion of different types of carbon structures in the oil. This is shown in Figure 3, displaying that the majority of the shale oil is made up of aromatic structures. Since the H/C ratio is related to the amount of aromatic compounds in an oil, Figure 2 confirms this and also suggests that kukersite shale oil is more aromatic than conventional petroleum. In fact, kukersite oil seems to more closely follow the trend given by coal liquids, which is logical because both contain large amounts of aromatic hydrocarbons. Indeed, coal liquids have often been used for producing aromatic chemicals such as benzene, toluene, and xylenes. In particular, kukersite shale oil contains large amounts of phenolic compounds [9], and the largest drop in $\mathrm{H} / \mathrm{C}$ ratio is caused by these compounds. Fractions boiling below about $200{ }^{\circ} \mathrm{C}$ contain relatively few phenols. Then the content of phenols increases quickly in fractions taken between 200 and $350{ }^{\circ} \mathrm{C}$. As seen from Figure 2, this is just the temperature range where the $\mathrm{H} / \mathrm{C}$ ratio decreases most rapidly. However, many of these phenolic compounds also have long straight aliphatic side chains, which is likely the reason that kukersite fractions still have higher $\mathrm{H} / \mathrm{C}$ ratios than the respective coal liquid fractions. Additionally, the lower $\mathrm{H} / \mathrm{C}$ ratios for light kukersite fractions are likely due to the alkenes in these fractions $[12,20]$. In the heaviest fractions, 


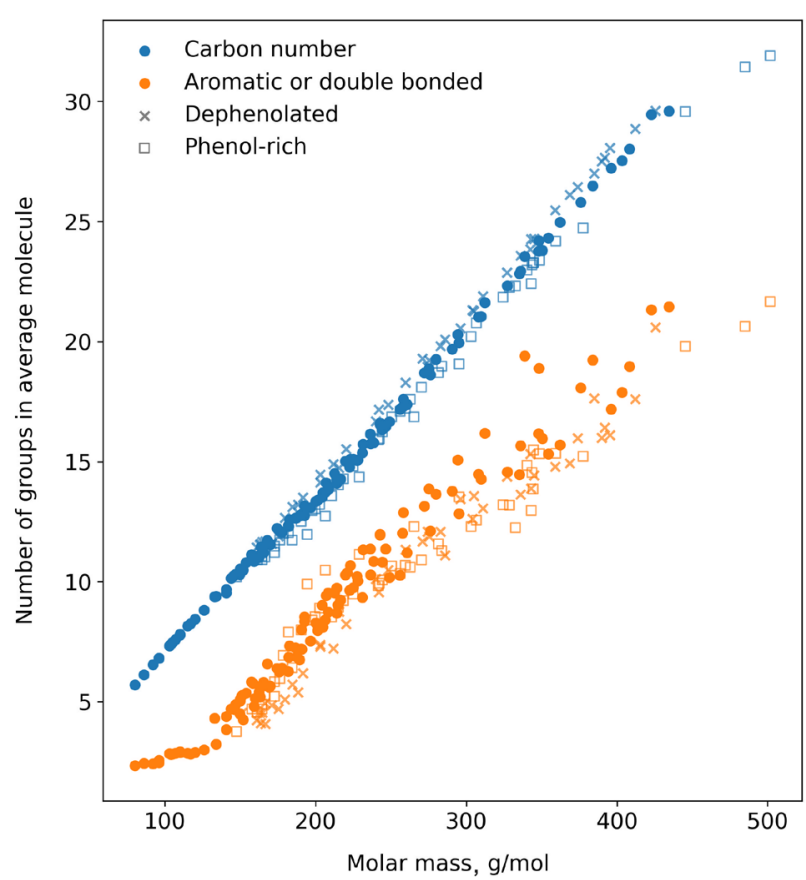

Fig. 3. Number of total carbon atoms and aromatic or double bonded carbon atoms in average kukersite shale oil molecules.

Figure 3 shows that the average molecule has more than 10 aromatic or double bonded carbon atoms, which indicates that multiring structures are common.

It is worth noting that Green River, Fushun and Sévérac-le-Château shale oils do fall within the petroleum region. This shows that the composition of shale oils can vary greatly depending on the source oil shale.

Using the infrared spectra, it was also possible to estimate which portion of the saturated carbon atoms were methyl groups and which were methylene groups. Figure 4 shows how kukersite shale oil contains more methylene groups, which is likely related to the straight alkyl chains attached to many of the aromatic molecules. The number of methyl groups is relatively independent of the average size of the molecule. For fractions with a molar mass of around $200 \mathrm{~g} / \mathrm{mol}$ (which corresponds to a boiling point of about $300{ }^{\circ} \mathrm{C}$ [12]) there is a drop in the number of methylene groups. This portion of the oil contains many phenolic compounds with short alkyl side chains, which would explain the drop [9]. Indeed, the dephenolated fractions (marked with $\mathrm{x}$ in Figure 4) do not exhibit this same drop. The fractions with low molecular weights generally contain more alkanes $[12,20]$ and those with the highest molecular weights have longer alkyl side chains [9]. 


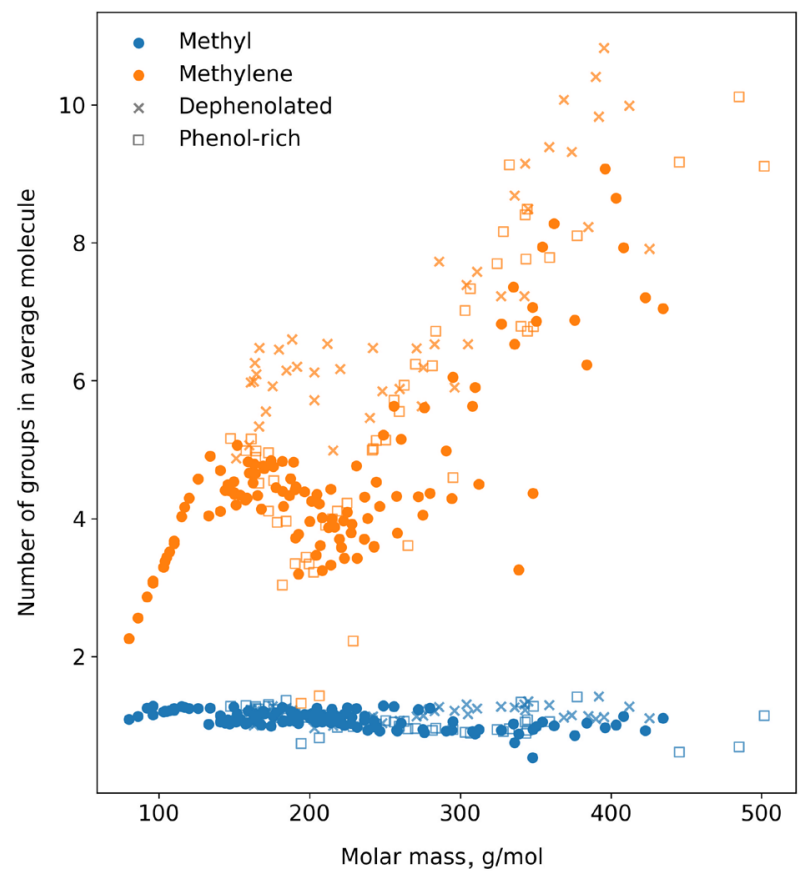

Fig. 4. Average number of methyl and methylene groups in shale oil molecules from various fractions.

\subsection{Oxygen groups}

Figure 5 shows that a maximum in oxygen content occurs with fractions boiling at about $320{ }^{\circ} \mathrm{C}$. This corresponds to the distribution of hydroxyl groups in kukersite fractions as reported earlier by Baird et al. [9], which is expected because phenolic compounds make a significant contribution to the oxygen content of the fractions. Kukersite also contains some carboxyl groups, and on the infrared spectra a $\mathrm{C}=\mathrm{O}$ stretch peak at approximately $1720 \mathrm{~cm}^{-1}$ was seen for all of the fractions [12]. Derenne et al. [30] also observed the presence of ketones in kukersite pyrolysis products.

When comparing kukersite shale oil to that from other oil shales, it can be seen that kukersite shale oil has an exceptionally high oxygen content. Again, this emphasizes how the composition can vary dramatically for shale oils created from different oil shales. Also, this explains why properties and models for other shale oils or petroleum often do not adequately describe the properties of kukersite shale oil.

We were able to estimate how many of the oxygen functional groups were phenols and organic acids and how many were neutral oxygen groups (e.g. aldehydes, ketones, ethers). This was done using a machine learning model developed by Baird et al. [9] and by Baird [17]. From the results in Figure 6, we see that generally about $2 / 3$ of the oxygen groups are phenolic (or acidic). There were some samples that had about an equal number of phenolic and 
neutral groups, and these samples were all prepared from fuel oil from the newer Enefit 280 plant.

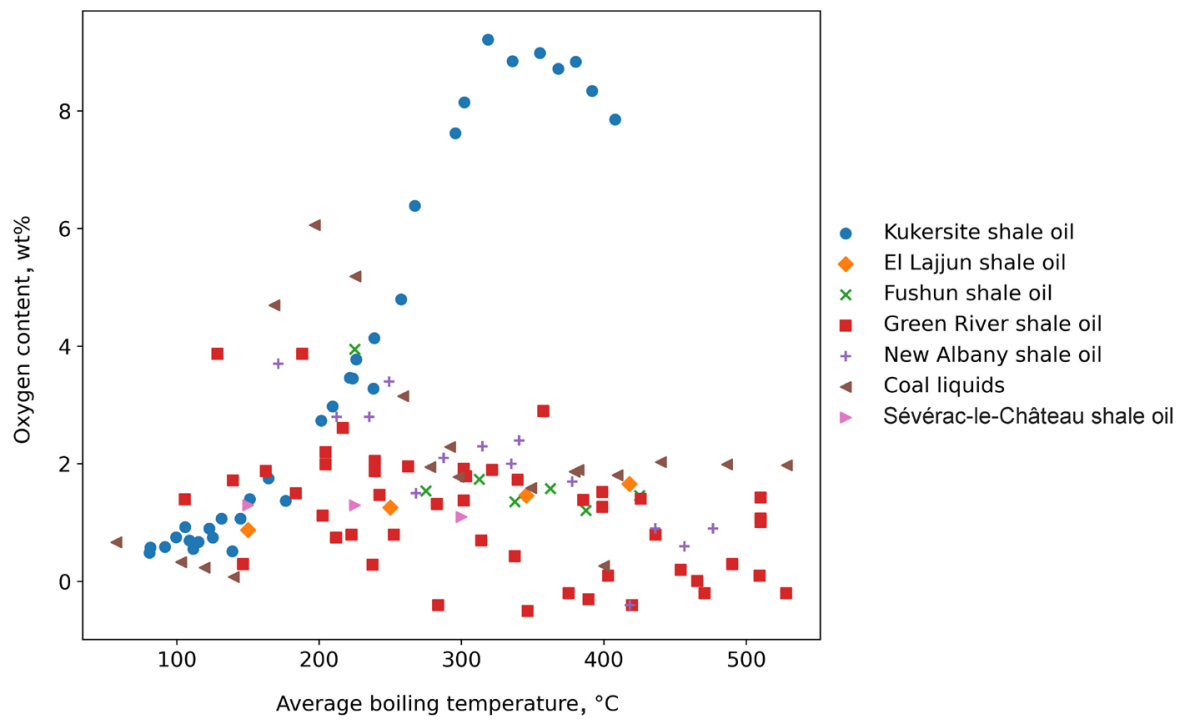

Fig. 5. Oxygen distribution of various shale oils. Literature data is from $[22,23,25-$ 27, 31].

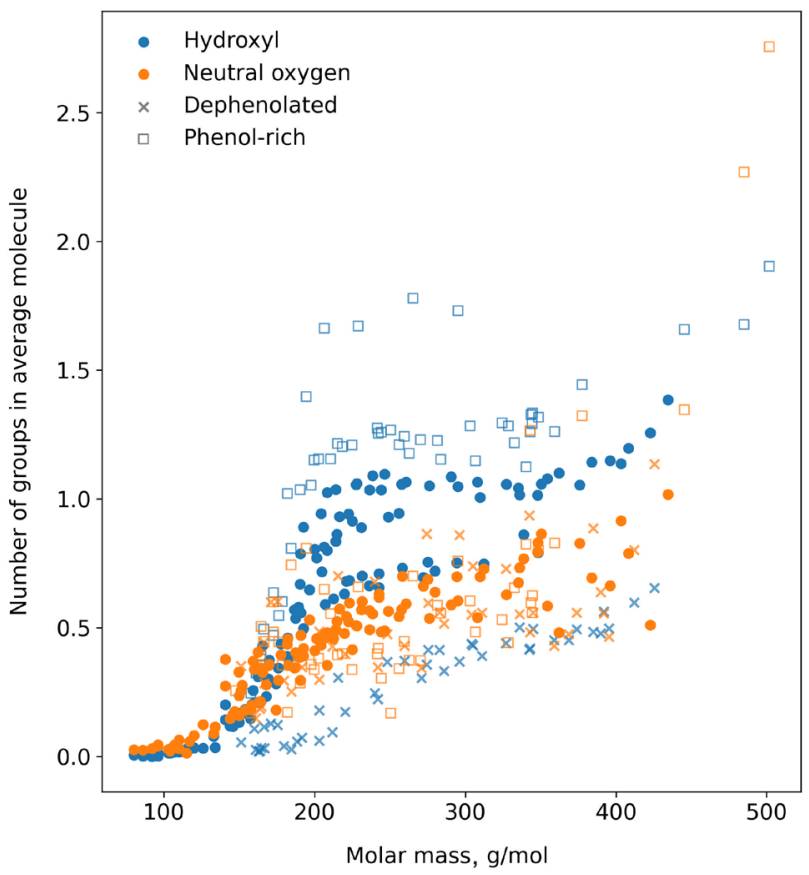

Fig. 6. Number of oxygen groups in an average molecule of different kukersite shale oil fractions. 
And, consistent with the trends seen with hydrocarbon groups, at a boiling point of around $300{ }^{\circ} \mathrm{C}$ (molar mass of $200 \mathrm{~g} / \mathrm{mol}$ ) the amount of oxygen compounds in the oil increases significantly. For the heaviest fractions, though, the mass fraction of oxygen decreases again, but the number of phenolic groups per molecule remains roughly the same. This shows that the largest molecules in the oil are still mostly phenols, but the hydroxyl group makes up a smaller portion of the molecule $[9,17]$.

\subsection{Sulfur compounds}

Crude kukersite shale oil usually has a sulfur content between 0.4 and $1.2 \mathrm{wt} \%$. As seen from the distribution given in Figure 7, the sulfur concentration is highest in the fractions boiling between about 150 and $190{ }^{\circ} \mathrm{C}$. In higher boiling fractions the sulfur content is lower and relatively constant.

Past studies have determined that the sulfur compounds in kukersite oil are mostly alkylthiophenes and thioesters, although some mercaptans and disulfides are also present $[13,30,32]$.

This type of sulfur distribution is different from that normally seen with conventional petroleum. For conventional fuels, the sulfur content generally continues to increase with the average boiling point of the fraction [33]. Coal liquid fractions also show a continual increase in the sulfur content [28]. Other shale oils, however, seem to have a distribution which resembles that of kukersite shale oil, as Figure 7 shows. Even Jordanian El Lajjun shale oil, which is known for its high sulfur content, shows a decrease in sulfur content in the heavier fractions [26]. A more detailed analysis of the sulfur compounds in kukersite shale oil is given by Mozzafari et al. [13].

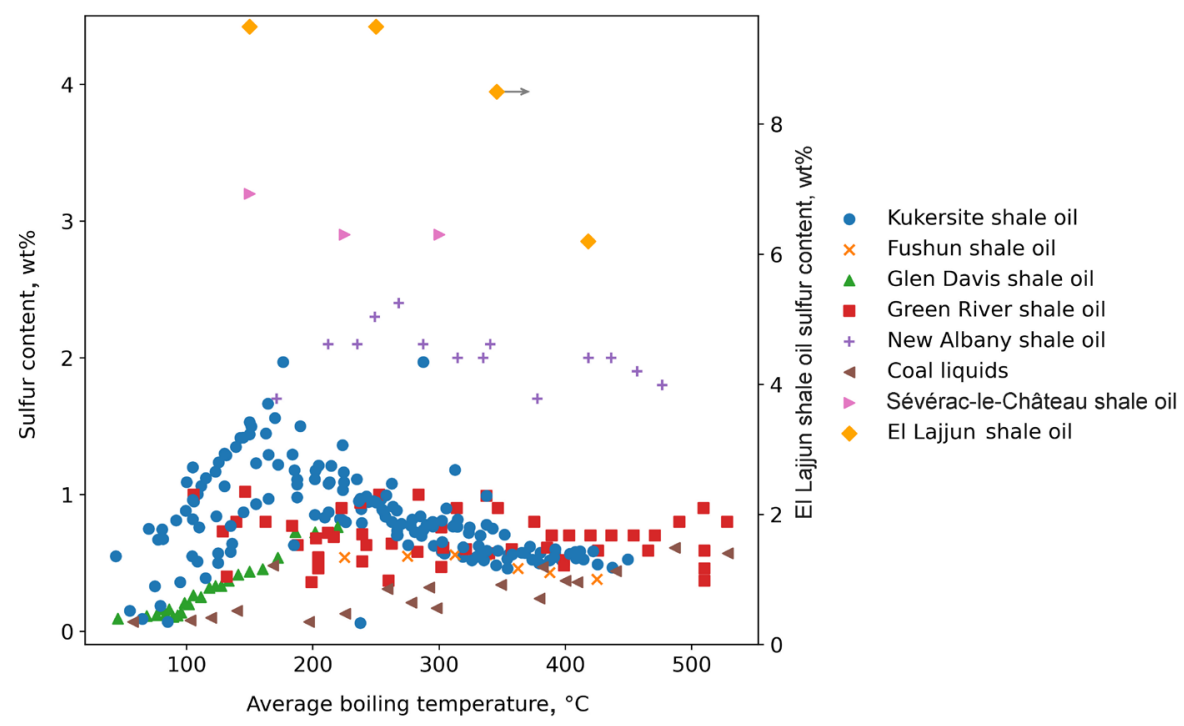

Fig. 7. Sulfur distribution of various shale oils. Note that the scale for El Lajjun shale oil has been placed on the second axis. Literature data is from [21-27, 31, 34]. 


\subsection{Nitrogen compounds}

The nitrogen content of crude kukersite shale oil is generally about 0.2 to $0.3 \mathrm{wt} \%$. Figure 8 shows the distribution of nitrogen content among kukersite fractions, and as can be observed, there is a steady increase in the nitrogen content as the average boiling point of the fraction increases.

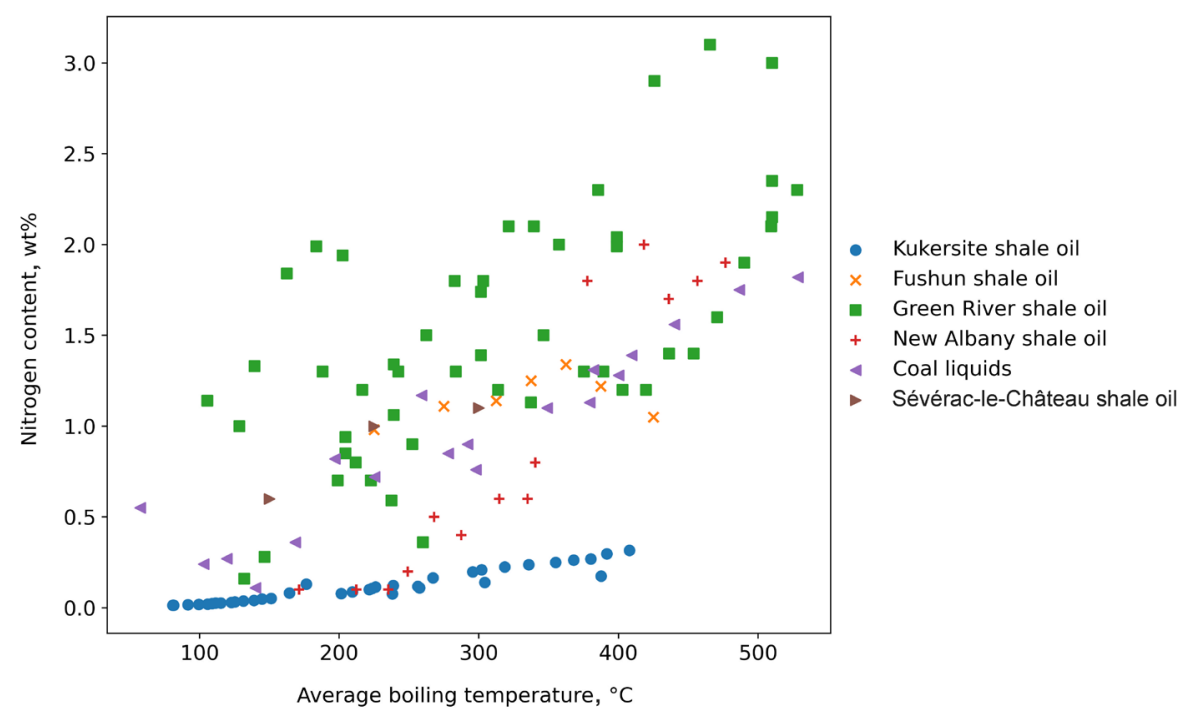

Fig. 8. Nitrogen distribution of various shale oils. Literature data is from [21-28, 31, 35].

This trend is similar to what is observed with other oils. Generally, heavier petroleum fractions contain more nitrogen [29]. Coal liquids also show an increase in nitrogen content as the boiling temperature increases [28]. This kind of distribution is also seen with some other shale oils, including Green River [21, 22, 24, 25, 31, 35], Sévérac-le-Château [27], Fushun [26] and some Paraiba Valley shale oils (Brazil) [31]. From Figure 8 it may be seen that Fushun shale oil undergoes a decrease in heavier fractions, but the residue that was left at $450{ }^{\circ} \mathrm{C}$ contained the most nitrogen of any fraction $(1.67 \mathrm{wt} \%)$.

\subsection{Potential molecular structures}

Based on the analysis above, we can give a small glimpse into what some of the molecules in kukersite shale oil might look like (see Fig. 9). It is important to remember that oils are very complex mixtures and Figure 9 in no way captures the full breadth of the variety of molecules present. The molecules shown with boiling points below $200{ }^{\circ} \mathrm{C}$, except for 2-methylthiophene, have been experimentally identified in kukersite shale oil by Gubergrits et al. [20] (data also available in [12]). 2-methylthiophene has been identified earlier in our own laboratory using GC-FPD-MS measurements. For molecules with 


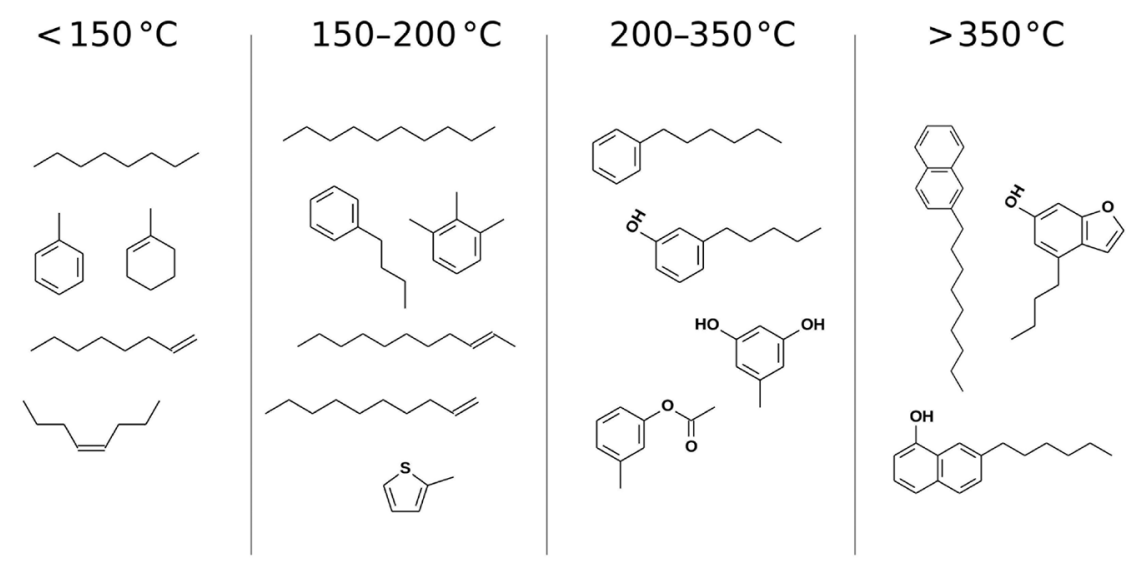

Fig. 9. Representative molecules showing some of the main structures found in different fractions of kukersite shale oil. These molecules are only for illustrative purposes and do not capture the full complexity of the oil.

boiling points above $200{ }^{\circ} \mathrm{C}$, to our knowledge only 5-methylresorcinol has been verified to be present [36]. The other molecules are representative of the molecular structures our analysis identified in these heavier fractions, but it should be noted that the presence of these exact compounds has not been experimentally verified.

The molecules in Figure 9 help to show the trends we noticed in our analysis. The gasoline fraction (boiling range up to $200^{\circ} \mathrm{C}$ ) is more aliphatic and contains fewer heteroatoms. The largest quantities of sulfur compounds are distilled towards the end of that range. However, the gasoline fraction only accounts for probably around $20 \%$ of the crude shale oil and most of kukersite shale oil consists of higher boiling aromatic compounds [12, 14]. In progressively heavier fractions of the oil, these aromatic compounds increase in size both by having multiple rings and by having longer alkyl side chains. The majority of these alkyl side chains are straight, not branched. These straight aliphatic chains can also be seen in the structure of raw kukersite kerogen proposed by Lille et al. [37]. Most of these aromatic compounds also contain oxygen atoms, most often hydroxyl groups.

The aromatic compounds are generally substituted at the 1, 3, and 5 positions, as has been shown by Derenne et al. [30]. This type of structure can also be seen in the kerogen structure proposed by Lille et al. [37].

However, one noticeable difference is that the oil fractions we measured have more aromatic carbon atoms than were found in the kerogen structure by Lille et al. [37]. Based on the NMR spectra they measured, only $21.7 \%$ of the organic carbon in raw kukersite oil shale is aromatic. We observed many more aromatic carbon atoms in the oil, which implies that condensation reactions occurring during the pyrolysis process make the oil more aromatic. 


\subsection{Effect on properties}

Composition is, naturally, related to the properties of the oil. For instance, the average boiling point of oil fractions increases as the molar mass (or carbon number) increases. This was seen in our analysis as well. For some properties, the number of hydroxyl groups also has a high impact. One example of this is density. Figure 10 shows how the density of the oil fractions studied varied depending on the composition of the sample. The amount of some functional groups did not appear to have any effect on the density, but the number of hydroxyl groups has a significant impact. For fractions with the same molar mass, having more hydroxyl groups increased the density.
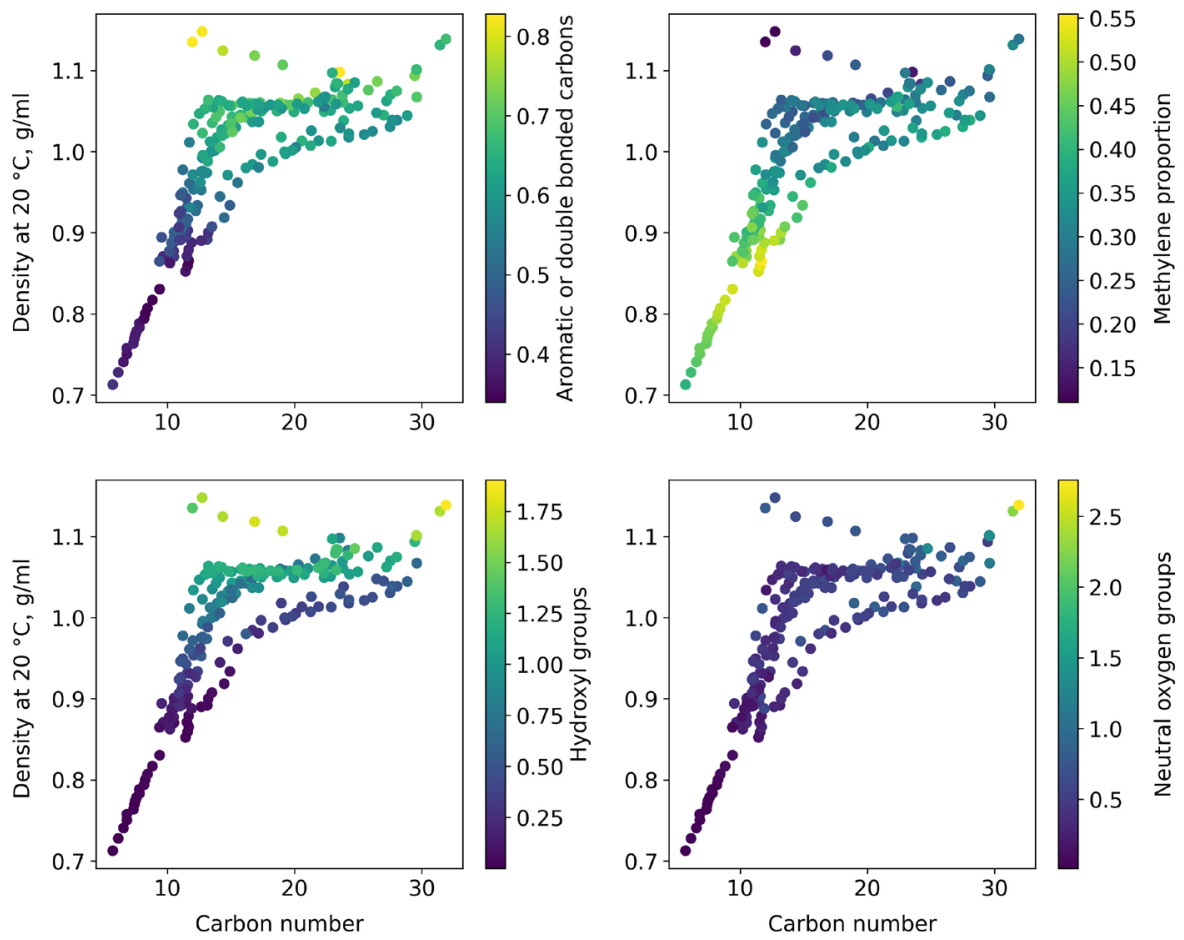

Fig. 10. Relationship between density and the amount of various functional groups. 


\section{Conclusions}

Kukersite shale oil generally has more heteroatoms than conventional petroleum and a larger proportion of aromatic compounds. The nitrogen content in kukersite oil increases continually with the boiling point of the fraction, which is a trend similar to that seen with other oils. For sulfur and oxygen compounds, however, the highest concentration occurs in the middle distillates. Sulfur content reaches a maximum for fractions boiling between about 150 and $190{ }^{\circ} \mathrm{C}$ and then is lower for higher boiling fractions. The maximum amount of oxygen occurs for fractions with boiling points around $320^{\circ} \mathrm{C}$. The elemental composition for crude kukersite shale oil usually varies within the limits of 81.0-85.0 C, 9.5-11.0 H, 0.4-1.2 S, 0.1-0.6 N, 5.5-7.0 O, all in $w t \%$.

Analyzing infrared spectra of the oil samples also showed that most of the saturated carbon atoms are methylene groups and on average a shale oil molecule has a single straight alkyl side chain. Kukersite oil fractions also have a higher oxygen content and a lower $\mathrm{H} / \mathrm{C}$ ratio than many other shale oils, which highlights how the composition of shale oil can vary significantly depending on the type of oil shale it is produced from.

\section{Acknowledgements}

The authors are grateful for financial support from the National R\&D program "Energy", under Project Nr. AR10129, from the Estonian Ministry of Education and Research, under Target Financing Nr. SF0140022s10, and from the Estonian Research Council within the framework of the National Programme for Addressing Socio-Economic Challenges through R\&D (RITA). Silvia East is thanked for measuring the sulfur and nitrogen composition of some of the shale oil samples.

The publication costs of this article were covered by the Estonian Academy of Sciences.

\section{REFERENCES}

1. World Energy Council. World Energy Resources: 2013 Survey. World Energy Council, London, 2013.

2. Bartis, J. T., LaTourrette, T., Dixon, L., Peterson, D. J., Cecchine, G. Oil Shale Development in the United States: Prospects and Policy Issues. Rand Corporation, 2005.

3. IPCC. Climate Change 2014: Synthesis Report. Contribution of Working Groups I, II and III to the Fifth Assessment Report of the Intergovernmental Panel on Climate Change. Intergovernmental Panel on Climate Change, Geneva, 
Switzerland, 2014. https://www.ipcc.ch/report/ar5/syr/ (accessed: Nov. 01, 2019).

4. PETROBRAS. Shale Industrialization Unit (SIX). https://petrobras.com.br/en/ our-activities/main-operations/refineries/shale-industrialization-unit-six.htm (accessed Aug. 24, 2021).

5. Nikolajev, J. Eesti Energia uus õlitehas sai nurgakivi. ERR, Nov. 16, 2021 (in Estonian). https://www.err.ee/1608404858/eesti-energia-uus-olitehas-sainurgakivi (accessed Jan. 26, 2022).

6. Lee, S. Oil Shale Technology. CRC Press, 1990.

7. Oja, V., Suuberg, E. M. Oil shale processing, chemistry and technology. In: Encyclopedia of Sustainable Science and Technology (Meyers, R. A., ed.). Springer-Verlag, New York, 2012, 7457-7491.

8. Kogerman, P. N. On the Chemistry of the Estonian Oil Shale "Kukersite." Oil Shale Research Laboratory, Tartu, Estonia, 1931.

9. Baird, Z. S., Oja, V., Järvik, O. Distribution of hydroxyl groups in kukersite shale oil: Quantitative determination using Fourier transform infrared (FT-IR) spectroscopy. Appl. Spectrosc., 2015, 69(5), 555-562. https://doi.org/10.1366/1407705

10. Neshumayev, D., Pihu, T., Siirde, A., Järvik, O., Konist, A. Solid heat carrier oil shale retorting technology with integrated CFB technology. Oil Shale, 2019, 36(2S), 99-113.

11. Golubev, N. Solid oil shale heat carrier technology for oil shale retorting. Oil Shale, 2003, 20(3S), 324-332.

12. Järvik, O., Baird, Z. S., Rannaveski, R., Oja, V. Properties of kukersite shale oil. Oil Shale, 2021, 38(4), 265-294.

13. Mozaffari, S., Järvik, O., Baird, Z. Sulfur in kukersite shale oil: its distribution in shale oil fractions and the effect of gaseous environment. OSF Prepints, Nov. 23, 2021, doi: 10.31219/osf.io/b8x6w; J. Therm. Anal. Calorim., 2022, 147(20), 11601-11610. doi: 10.1007/s10973-022-11359-8

14. Järvik, O., Oja, V. Molecular weight distributions and average molecular weights of pyrolysis oils from oil shales: Literature data and measurements by size exclusion chromatography (SEC) and atmospheric solids analysis probe mass spectroscopy (ASAP MS) for oils from four different deposits. Energy Fuels, 2016, 31(1), 328-339, doi: 10.1021/acs.energyfuels.6b02452

15. RDKit: Open-Source Cheminformatics Software. http://www.rdkit.org/ (accessed Mar. 02, 2020).

16. Ertl, P., Rohde, B., Selzer, P. Fast calculation of molecular polar surface area as a sum of fragment-based contributions and its application to the prediction of drug transport properties. J. Med. Chem., 2000, 43(20), 3714-3717, doi: 10.1021/ jm000942e

17. Baird, Z. S. Predicting Fuel Properties from Infrared Spectra. PhD thesis, Tallinn University of Technology, TUT Press, Tallinn, Estonia, 2017.

18. Aarna, A., Paluoja, V. Determination of hydroxyl groups in shale oil by the acetylation method. In: Analytical Methods for Oil Shale and Oil Shale Products. 1961, Tallinn, Estonia, 23-26 (in Russian). 
19. Coates, J. Interpretation of infrared spectra, a practical approach. In: Encyclopedia of Analytical Chemistry (Meyers, R. A., ed.). John Wiley \& Sons, Ltd., 2006.

20. Gubergrits, M. J., Rohtla, I., Elenurm, A., Myasoyedov, A. M. Comparison of light oil products from oil shale retorting in solid heat carrier units UTT-3000 and UTT-500 (in Russian). Oil Shale, 1989, 6(2), 189-194.

21. Miknis, F. P. Characterization of DOE Reference Oil Shale: Tipton Member, Green River Formation Oil Shale From Wyoming. Topical Report. Western Research Institute, Laramie, WY, USA, DOE/MC/11076-2676, 1988.

22. Miknis, F. P., Robertson, R. E. Characterization of Doe Reference Oil Shales: Mahogany Zone, Parachute Creek Member, Green River Formation Oil Shale, and Clegg Creek Member, New Albany Shale. Technical Report. Western Research Inst., Laramie, WY, USA, DOE/MC/11076-2448, 1987. http://www. osti.gov/scitech/biblio/5535457 (accessed Dec. 01, 2016).

23. Lovell, P. F. Production of Utah Shale oils by the Paraho DH and Union 'B' retorting processes. In: Eleventh Oil Shale Symposium Proceedings (Gary, J. H., ed.). Colorado School of Mines Press, Golden, Colorado, 1978, 184-192.

24. Hill, G. R., Dougan, P. The characteristics of a low temperature in situ shale oil. 96th Annual AIME Meeting, Los Angeles, Calif., Feb. 19-23, 1967.

25. Bunger, J. W. Shale Oil Value Enhancement Research. James W. Bunger and Associates, Inc., Salt Lake City, UT, USA, 2007.

26. Qian, J., Yin, L. Oil Shale: Petroleum Alternative. China Petrochemical Press, Beijing, 2010.

27. Marecaux, P. P. Essais de valorisatsion integrale des huiles de schiste de Severac. In: Oil Shale and Cannel Coal, 1951, 2, Institute of Petroleum, London, WI, USA, 673-689.

28. Gray, J. A., Brady, C. J., Cunningham, J. R., Freeman, J. R., Wilson Grant, M. Thermophysical properties of coal liquids. 1. Selected physical, chemical, and thermodynamic properties of narrow boiling range coal liquids. Ind. Eng. Chem. Process Des. Dev., 1983, 22(3), 410-424.

29. James G. Speight. Crude Oil Assay Database. Knovel, 2015. https://app.knovel. com/web/toc.v/cid:kpCOAD0005/viewerType:toc/root_slug:crude-oil-assaydatabase/url_slug:crude-oil-assay-database (accessed Sep. 23, 2016).

30. Derenne, S., Largeau, C., Casadevall, E., Sinninghe Damsté, J. S., Tegelaar, E. W., de Leeuw, J. W. Characterization of Estonian Kukersite by spectroscopy and pyrolysis: Evidence for abundant alkyl phenolic moieties in an Ordovician, marine, type II/I kerogen. Org. Geochem., 1990, 16(4-6), 873-888, doi: 10.1016/0146-6380(90)90124-I

31. Cady, W. E., Seelig, H. S. Composition of shale oil. Ind. Eng. Chem., 1952, 44(11), 2636-2641, doi: 10.1021/ie50515a044

32. Zelenin, N. I., Fainberg, V. S., Chernysheva, K. B. The Chemistry and Technology of Shale Oil. Chemistry Publishing House, Leningrad, 1968 (in Russian).

33. Riazi, M. R. Characterization and Properties of Petroleum Fractions. ASTM International, 2005. 
34. Mapstone, G. E. Density-temperature relationships of shale oil products. In: Oil Shale and Cannel Coal. 1951, 2, London, WI, USA: Institute of Petroleum, 710 712 .

35. Dinneen, G. U., Allbright, C. S., Ball, J. S. Comparison of Brazilian and Colorado shale oils. Ind. Eng. Chem. Chem. Eng. Data Series, 1956, 2(1), 91-95, doi: 10.1021/i460002a026

36. Eesti Energia, Viru Keemia Grupp, Oil Shale Competence Center at the Taltech Virumaa College. Estonian Oil Shale Industry Yearbook 2019 (Oone, A., ed.). https://haldus.taltech.ee/sites/default/files/2021-04/VK_eesti_polevkivitoostuse_ aastaraamat_en_2019.pdf?_ga=2.94444828.1831482186.16296980872065338881.1627903036 (accessed Aug. 23, 2021).

37. Lille, Ü., Heinmaa, I., Pehk, T. Molecular model of Estonian kukersite kerogen evaluated by ${ }^{13} \mathrm{C}$ MAS NMR spectra. Fuel, 2003, 82(7), 799-804, doi: 10.1016/ S0016-2361(02)00358-7

\section{Appendix}

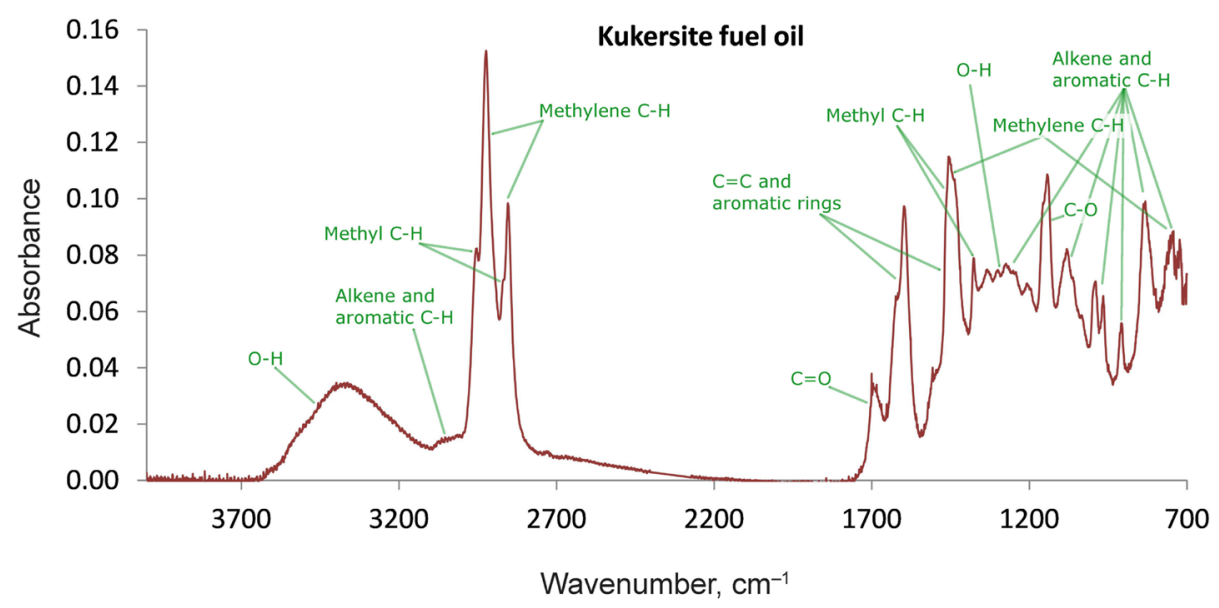

Fig. 11. Infrared spectrum of a kukersite fuel oil fraction showing the functional groups associated with various peaks. Group assignments are based on the information provided by Coates [19]. 